\title{
The treatment of empyema thoracis
}

Harvey E. Pinto

University of Nebraska Medical Center

This manuscript is historical in nature and may not reflect current medical research and practice. Search PubMed for current research.

Follow this and additional works at: https://digitalcommons.unmc.edu/mdtheses

Part of the Medical Education Commons

\section{Recommended Citation}

Pinto, Harvey E., "The treatment of empyema thoracis" (1931). MD Theses. 171.

https://digitalcommons.unmc.edu/mdtheses/171

This Thesis is brought to you for free and open access by the Special Collections at DigitalCommons@UNMC. It has been accepted for inclusion in MD Theses by an authorized administrator of DigitalCommons@UNMC. For more information, please contact digitalcommons@unmc.edu. 
THE TRFATIFIT OF ERPYEA THORACIS

\author{
A Senior Thesis \\ Prepered and Written by \\ Harvey E. Pinto \\ April, 1931.
}


The Treatment of Empyeme Thorecis

The cheotic condition in which the treatment of empyema found itself during the World wer wes tiken account of by the Surgeon General of the United Stetes; whereupon, in 1918, he appointed en empyene comission to study the situation, and advise thereupon. After some months, the comission wes able to suggest drastic measures changing the treatment and management, most noteworthy of which was the postponement of the time of operation. The reformetion, however, did not succeed in accomplishing ell thet wes enticipeted. Insterd, it left the situetion in very nerrly as tumultous a condition, in regerd to the choice of operation, as it hed been previously in regerd to the time of operetion. The last word hes not, as yet, been spoken, and, from all apperences, it looks as though considerable time would elapse before cny universel opinion cen prevail. Needless to sey, there ere verious types of cases which, in the opinion of meny, require different modes of treatment. Whether this opinion will continue indefinitely, or not, remains to be seen. Before $\varepsilon$ consideretion of the verious types of treatment is attempted, it would be well to teke into account $\varepsilon$ snep shot of the verious types of empyeme which might obtein enatomically. First, there could be a totel, or generel, empyeme, 
Treatment of Impyeme. Thorecis

involving the entire pleural cevity, and causing more or less collepse of the lung. (See Figure I.)

$$
\text { Fig I. }
$$

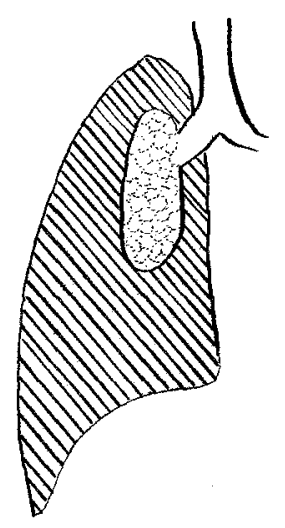

On the other hand, there could be the sacculeted empyeme, of which there ere severcl varieties. One of these js the socalled perietel empyeme, occuring between the lung and the chest wi 11. (See Figure II.)

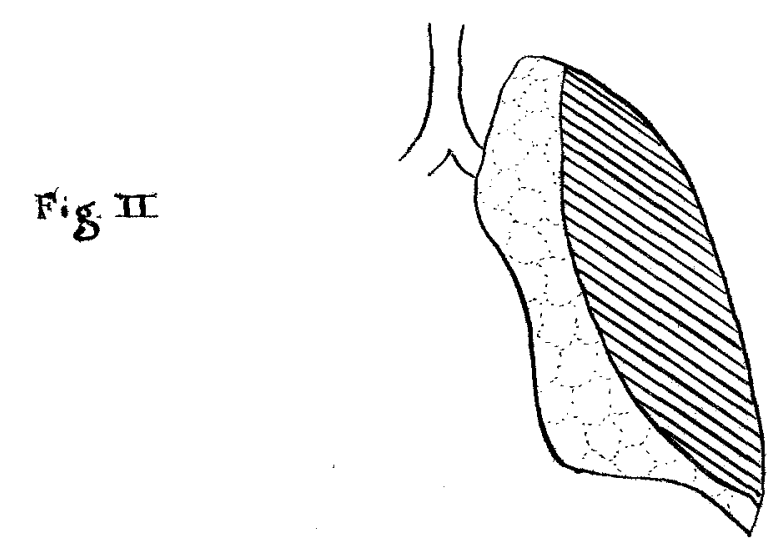

Another, the mesic I veriety, occurs between the lung and the mediestinal pleura. (Figure III.) 


\section{Fig IIr}

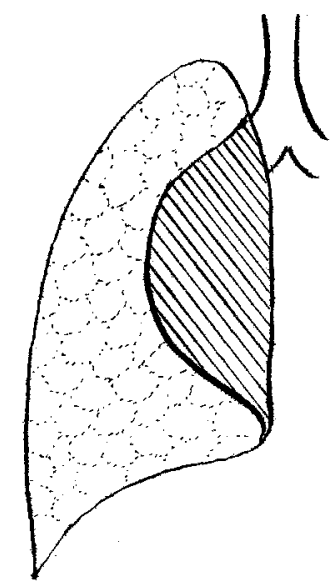

Another type is the supra-diephragmetic occurring between the lung and the diephregm. ( See Figure IV.)

Fig. IV.

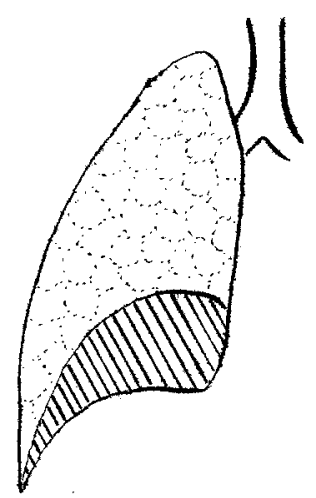

Still enother variety is the interlober empyene which is selfexplanetory. (See Figure V.)

Fig. I

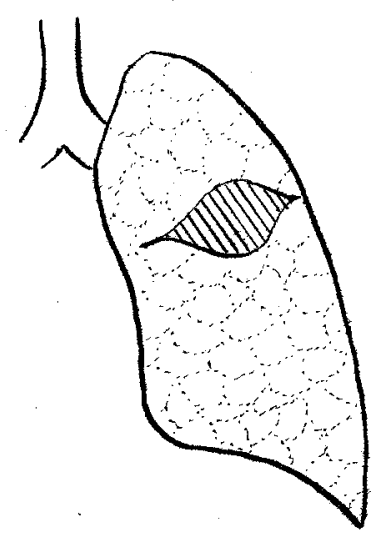


Treatment of Tmpyeme Thorecis

Oftimes, empyemes are clessified according to the position of the lung or pleurs involved, as, for example, apicel or leteral empyemes. Sometimes, clessificctions teke into account whether or not the empyeme is adherent. An interlobar type of empyeme, for exemple, is usueliy non-edherent; wheres, a letercl, apicel, or supra-diephrogmetic is usuelly edherent. one is virtuelly forced into considering the etiology of empyema before one can stisfectorily begin treetment. Just as with a great meny other diserses, the eti logy is not constant, but veries widely. It should not be forgotten that the etiology varies according to whether the empyeme is eccute or chronic. Pneumonic is, of course, the most common ceuse of accute empyema thoracis. Other causes are gengrene of the lung, septiceric, influenze, whooping cough, neesles, tuberculosis, and primery (idiopethic) empyeme. The most neturel route of entrence of organisms post-operative following generci ancesthesia would be by inspiration of the orel secretions. It is probeble that many empyemas develop without well-defined clinical manifestations of an abscess or gengrene of the lung. The explanetion is this, that en espiration broncho-pneumonie follows the operetion. In explenation of this point, Pilot'seys that usuelly with liquifaction necrosis by the ane erobic becteric, end with the formetion of : pulmonary abscess, the pe- 
Treatment of Fmpyeme Thoracis

tient expectoretes typicel foul sputum on the twelf th to fifteenth doy. In a cese of his, he thinks this usuel monifestation wes prevented by the repid extension to the pleure, and the quick fornetion of fluid which collepsed the lung. He observes, further, thet, apparently, the empyeme wes not on extension from the peritoneum on ccount of the orgenioms found. Insteed of being, of the type of B.coli, or other intestinal orgenisms, they were like those observed in the orel cavity; thus his explenation.

Lastly, but probably not les importent fron an etiological standpoint, is the considerction of crecognized, demon strable anatoricel curiosity, -- thet is, thet there is some onatomical connection between the body cavities, as, for example, between the peritoneal and pleurcl cevities, or between the two pleurel cevities. Whether this plays i per in many, or in only a few of the pleurel infections, is not known; but, it is not improbeble thet it is much more inportent then hes been hitherto recognized.

Accute empyem thortis is not the surgicel emergency it wes once considered. 保ortality statistics show very derinitely that deleyed operation meterisily lessens the deeth rete. Three very definite cdvantages are cleimed by Hudson ${ }^{2}$ for de- 
Treetment of Ernpyeme Thorecis

layed operetion; first, the delay ellows the patient to acquire e pertial immunity; second, it allows the petient to recover from the residual toxenic of his pneumonia; and, third, it allows time for sufficient adhesions to form, thereby localizing the pleuritis and stabilizing the mediestinum. By acceptance of the wisdon of deferred operation, until well beyond the period when pulmonery inflemetion mey be expected to heve subsided, find thet the mortelity reduction is from forty per cent to five per cent. On this point alone, thet of defered operction, there is absolute egreement in medical ranks; on all other points in empyeme menagenent, there is disegreement. Imnediate operation has been relegeted to the bier of abondoned proceedures. Ambrose Lockwood says, "Few diseeses heve perplexe od the profession so Eenerelly since the eerliest tines, es hes empyeme." puoting further, "Even in this sdvenced ere of medical development, there is no agreement as to the treatment, as is evidenced by the warious methods edvoceted, the persistent incidence of chronic empyene, fnd the extrone veritions in mortelity." Hippocretes first reconnized tine disesse, and advised intercostal incision, or trephining of the rib for dreinage. Gelen, the inventor of the aspirating syringe, edvised spirction. The pertinent questions ere,- the nortelity 
Treatment of tmpyene Thoracis

rete, the length of illness or distbility, and the incidence

of chronic empyent; therefore, the method used must, of necess-

ity, be besed on the indiviacl operetor's experience, in the

opinion of Henry Iudson Junior. Obviously, the selection of the

type of case is a very importint elenent, especially as re-

gerds stetisticel compijetion. Difference of pinion exists be-

tween the advocktes of closed dreinge, and those of open drein-

8ge. Suermondt thinks thet the two methods should supplement

esch other.

The methods of treetment expounded by various surgeons include, first, simple sspiretion; second, closed dreinage (intercostel), two types of aich are closed dreinege without rib resect on, end closed dreinage efter pib resection, the aortelity rete of the former type being twice thet of the letter; ? third, open dreinege. There ere, in generei, two types of thorcotum which tre cveiltbie s procedures in the opertive Eproch. The first is ithout the dividion of either bone or certilege; the second is with the division or resection of pert of the thoracic cage. The former type is apliceble only before the chest well has becorne ricid as the result of pathologicel processes. The adventiges of the first method, the epproch by an intercostel incision with wide retrection of 
Trestment of Fmpyeme Thorecis

the ribs, cre, thet it is ecompenied by little shock; thet the exposure with good rib retrectio: is emple; thet, ell perts of the pleure, the mediestinu, end the pericerdiun being accessible, much tire is seved; thet the ayosition of the perts is sinost perlect, pleure being mede to join pleura with serous surfeces in contect; thet no ingortant nerves are cut; and that hecing is repid. The single discdventege of this wroceedare is that, when dreinage is required, it must usuelly be provided through another, though small, opening. As concerns the second method, resection of pert of the thorecic cage, there are three types, first of which is rib-resection, either single or multiple, two types of wich are sub-periosteal ribresection and resection of the rib with its periosteum; second, trep-door opening in the thorecic well, either temporery or permenent; and third, rib section supplementing on interoostel incision. Adventeges of this method arethet it pernits excellent exposure and grett elcsticity of the velis of the wound; thet it allows of repid operetion; that it jields Iittle post-operetive defornity; ond thet it is apticeble in acute cases asa well as in chronic ones.

In meking : diegnosis of accute empyeme thorecis, it is wise to suspect eny pneumonit petient, inasmuch as it 
Treatment of Empyeme Thoracis

occurs in from four to five per cent of 11 pneunonit petients. Physicel exmination mey show any of the following poirts: thorecic assymetry with scoliosis; bulgine interspaces; limited excursion of the effected side; dull or flet percussion note; displecement of the heart ewgy from the effected side; absent or dininished breeth sounds; tubular brecthing, if the effusion is grect; absent or diminished tectile fremitus; bleating cherEcter of the spoken voice; decressed redicbility; a presence of pus on diagnostic thorecentesis; end definite diagnostic shedows on fluoroscopy.

Just : word in regerd to the type of encesthesie needs to be scid. Of course, genere I ncesthesic my be used, and its indicetions and contre-indicetions are quite genereliy known. Among the adventeges of locel encesthesie, sccording to lilienthe $1^{5}$, is the fact thethetient is fully conscious, and con often be of grect assistance to the operetor. Irintre-thorecic work, he cen cough or strein, distending the lungs et will. He can chenge his position, at request, for the convenience of the operetor, avoiding the bxek in ssepsis and the other emnoyences of chengine the posture of e nercotized petient. There heving been no nercosis, tood end drink mey be token soon after the operation. The espirction of septic 
Trestment of Bmpyeme Thorecis

metter or blod irom the mouth, possibl/ coukhed up fron 8 disersed lung, is prectiocliy evoided. Some of the disedverntrges of locel the esthesie se thet, in certin opertions on the pleurs, ss, for exmple, acute end subecute empyena, an unevoideble cough reflex my be emberressing. Vomiting mey apeer, fnd be as troublesome as it is efter generil gneesinesie. Locel is contreindict ted dri extrenely nervous petients. In injecting the aree, it is veil to teke int accont the following points. The skin is sensitive, end must be tregted ccoordingIy. It is stated by Lennender thet "eIl internel orgens receiving their nerve supply only from the syupthetic and from the vagus below the brenching off of the recurrent nerve heve no sensetion". The subcuteneous connec ive tissue End aponeurosis show veriations, end should be treeted, or not, sccording to necessity. As o rule, hawever, it is found best to inject the deep frscia. The muscles are not peinful when cut, but their rough menipulation, as by retrectors, often gives rise $t$, a dull achine sensation, different from a sherp pain. The contraction following the division of en important muscle often produces $a$ disquieting and depressing sensetion. The periosteum is sensitive, and must be cnaestretized either by direct injection or by nerve blocking. The 
ribs and cartileges, when denuded of periosteun, mey be cut, screped, or chiseled without pein. Perietel pleure mey, or my not be sensitive. The Iung and viscert l pleure ere not sensitive to pizin, but erteries and their shecths ere.

Ir Hudson's clinic, the only two procedures used ere first, intercostel, closed drainege, and second, rib resection with open drainge. The first procedure is used on those petients who are so ill thet the more extensive rib resection is to be evoided beceuse of treume end shock; it is ased elso in infent ander one yorr, as a primery procedure, and in those petients with very thin exudte sud with a culare showng an orgenism other then the pneumococcus. The procedure followed in his clinic for the performence of intercoste l closed dreinege is this: the epproech is ade in the seventh or eighth interspace in the mid-exillery line following infiltretion with one per cent novocine. A one-helf inch skin incision is mede, and a trocer is plunged into the cavity efter aspiration has verified the localization of the cavity. The stylet of the trocer is replcced by a fenestreted rubber catheter, following which the trocer cylinder is renoved, and the cetheter clemped. Gauze and imbricated cdhesive are epplied, end the cetheter is led into 8 vessel below the level of the fluid conteined 
therein. The catheter is then wistened, and the closed system is esteblished.

Rib resection, fith concomitent inspection end pelpation of the empere cevity, is the other method used in Hudson's clinic, and it seens eltogether setisiectory. The postoperative hospitilizetion is shorter in this type of operetion, end the proportion of secondery operetions is less; elso the mortelity is lower, eighteen per cent to nine per cent. Ultreviolet therapy, es an adjunct to this type of operation, hes more velue, opperently, then it hes in the other type. Roeder tedvocates a gauze peck as enother method of treatment. In defense of his innuvtion, he siys, "One of the principel reasons for the origin of the closed method wes the thought thet air in en infected pleurel cevity wes detrimental, meinly through preventing an expension of the lung. The presence of air in en infected pleurel cavity hes never been proven to b be hermful, and the average epplication of the closed method of dreinage rarely prevents the ingress of eit." He concludes the it is not the presence of eir, but rether the leck of dreinge thet is the irportent consideration. By means of his geuze pak, he is eble to ceuse an obliteration of the cavity in from ten to thirty days if the visceral will of the cavity 
Tre tment of Fmpyeme Thoracis

is not too thick. The edventeges of the geuze peck method are enumercted by Roeder as follows: first, it holds the lung stexy following the operetion, which, of itself, is nost conforting to the petiont; second, it cleers the exudete repidt Iy from the walls of the cevity; third, it breaks up the numerous smell abscesses in the periphery of tine lung; fourth, it eredicetes externel purulent drainege elnost completely, efter forty-eight hours; and fifth, it obliterctes the cevity at leest as rapidy as does any other method. He notes, on the other hand, certein disedventeges, rirst that the peck must be changed deily by some one experienced, and, second, thet the first chenge post-operetive is distressful without light eneesthesic. For the evergge case, it is necessery to peck the cavity for from seven to ten deys with guze, inpregneted with bismuth iodide.

Fingstadt ${ }^{8}$ produces en effect of vecuum dreinage by e type of epperetus altogether different from the ordinery weter-seal drainge, which is illustreted below.

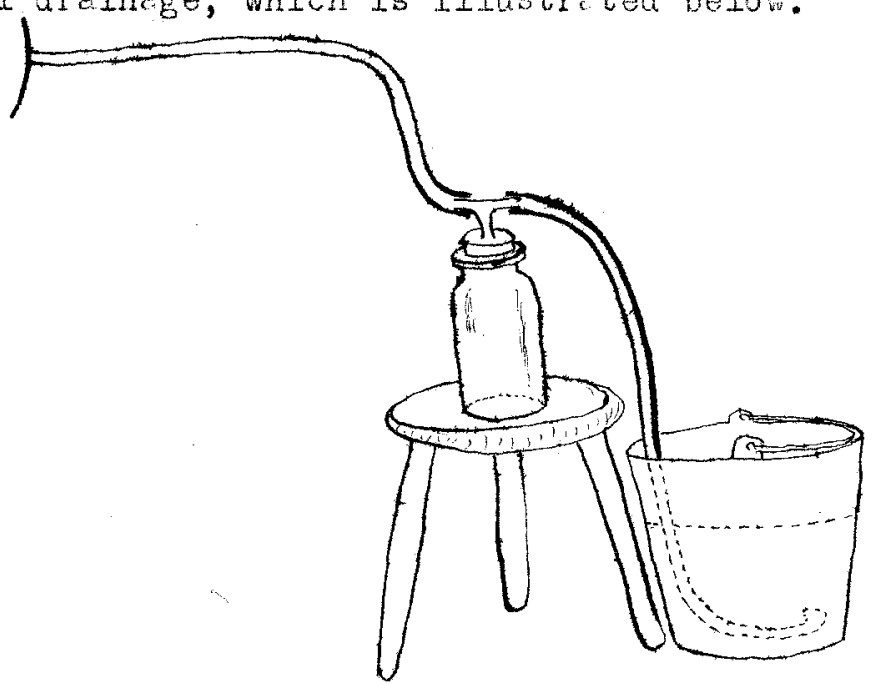


His method is to remove the valve stem of an inner tube with a surrounding ovel of rubber about three by four inches. To prevent lexkge, he glues this to the chest well with rubber cement. Next, he introduces a tightly fitting rubber cathoter into the thorax thro gh the valve stem. By removing pus and sir through the tube, using on ordinary Luer syringe to obtain suction, he is eble to form a pertiel vecuum which he meinteins by occluding the tube with e hemostet. This negetive pressure li sts ebout four deys, end cen be renewed eccording to circunstence.

A metrod besed on a retion 1 sounding theory is edvenced by punton. The principel on which his metrod is besed is this: a partial vecuum produces hyperemie; s dilatetion of the engorged vessels follows, and a flow of serum is pronoted through their wells, and into the empyeme covity. This serum provides the positive entiseptic agent required to overcome the infection. It bathes the cells of the affected area, and eventuelly collects in the empyene cevity, cerrying deed becteriv and toxins with it. The lung expends under the influence of the vacuum, and allows the infection to cleer up es well. The eppratus consists, fundemertally, of a fenestreted rubber tube, connected indirectly to E. Luer syringe. The 
Treatment of hinpyent wh racis

15.

rubber tube passes through 2 sheet of rubber which is dram well up on the rubber tube, and tied. The rubber sheeting ss plastered on its under surfece with zinc oxide peste to prevent eny leakge. Where the rubber tube penetretes the chest well, $\varepsilon$ piece of gless tubing is inserted into its lumen to prevent collapse. The dirgrem below shows the connections of the rubber tube to a catch bottle, end then to a syringe, with c side connection, interpolated betveen them, leading to pressure-regulating manometer which is mode of $\varepsilon$ gless funnel covered with rubber sheeting. The apperstus difficult to remove, and should, therefore, be

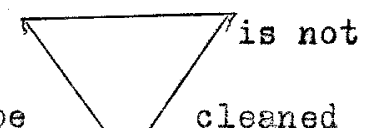
every doy

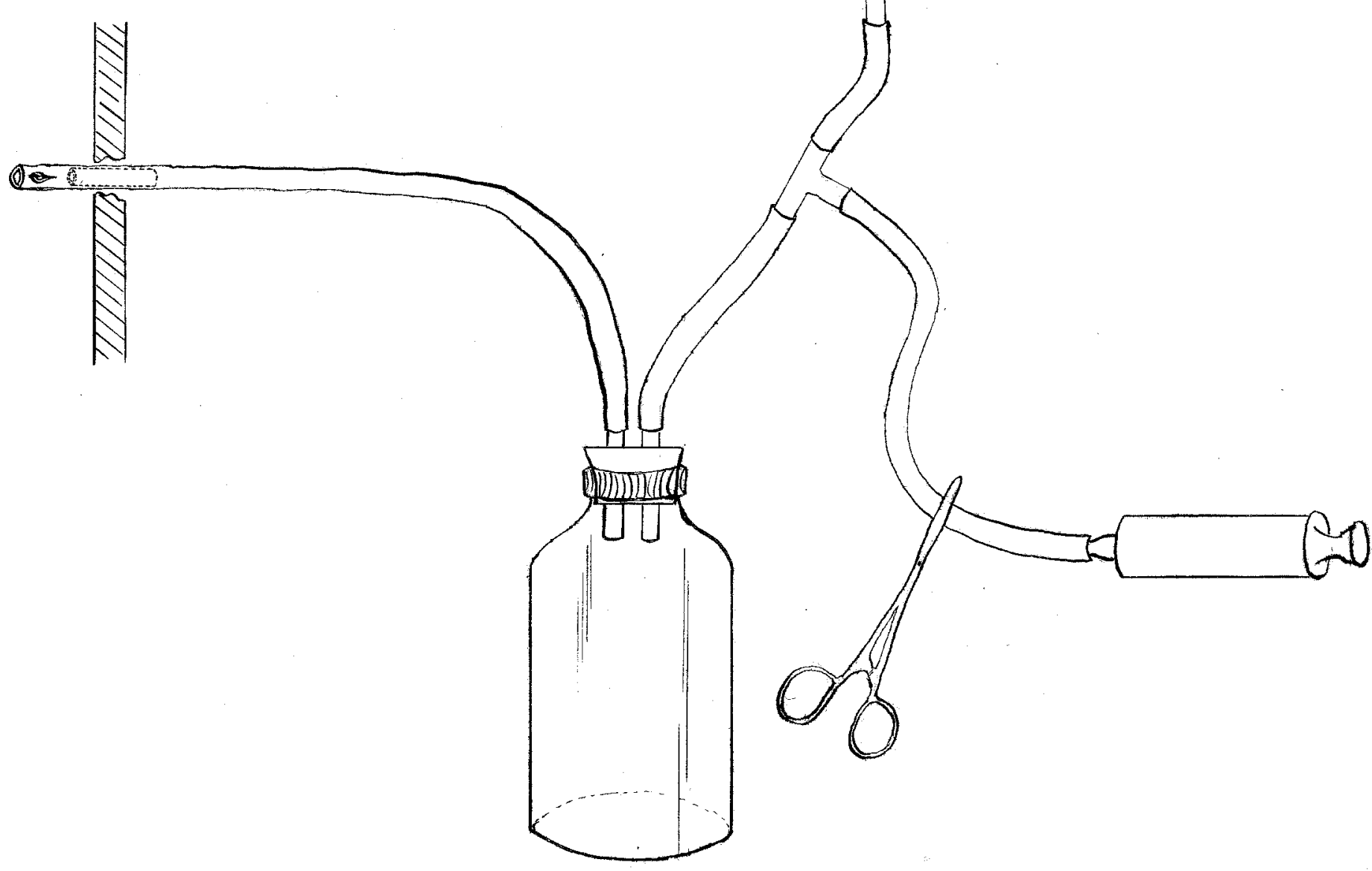


A vacuum draingge method of greater simplicity is

offerred by Mansur. An ordinery Milson tube is prepered 0 follows: over its external surface (the larger flenge side), is placed a sheet of rubber which is attached at one side only, using rubber cement. This simple proceecure makes one-wey valve-trap which, when placed in the chest will, will be found to offer no hindrebce to the escape of pus and air from the empyemic cavity, but will allow nothing to renter it. The tube is now further prepered just before introductioninto the chest well by having its smaller flange side rolled up, and held by t hemostet to fecilitete its eesy introduction into a smell chest weli opening. Then, efter selecting a suiteble site, usually in the mid-exillary line, the skin and deep structures are infiltreted with e locel anesthetic. The rib is resected for short distence. A sponge is held in the left hand while, with the right hend, a blunt forceps is forced into the empyemic cevity. The jaws are sepereted enough to meke a three-querters-inch opening. Immediately covering the wound With a gruze sponge, held in the left hand, to prevent immediEte escepe of the pus, the free hand introduces the valve under the sponge in to the chest wall. The operation of the velve my now be observed. The patient coughs slightly, end, 
es this increases intre-thorecic pressure, quentities of pus and eir rush out through the velve; then, es the thorecic well relexes, there is produced an intra-thorecic vecuum. The rubber tissue cover of the tabe will then be observed covering the tube opening tightly, through suction. Coughing will be frequent enough to mintain a constent intra-thorecic pressure. If the tube is allowed to remein in place for about four days after it has lost its efrectiveness, (usually a metter of severel weeks), then collepse of the lung need not be ferred. Replecing the velve will correct the collpese, however. In double empyema, this treatment will prove most valueble. At the New Hen Hospital, L. C. Foster luses a method on acute empyeme cases consisting of thorecentesis, delayed prirtial costectomy, and constant suction tube drainage. Single$\operatorname{ton}^{\prime 2}$ has method of inserting a trocer and cennule in the eighth Interspece in the mid-scepler line, and of allowing the cennuic to remein in place, stitched to the skin. A tube connection, filled with sterile weter, is led to a lere bottle beside the bed, and the end pleced under weter, thus reteining a vacuum, with siphon effect. The cannula is allowed to renein $\varepsilon-$ bout ten deys, and is then repleced by a rubber tribe.

There are as meny different trectments for acute 
empyem as there ere euthors discouring on the subject. Most are too complicated. In some instences suction is obteined, and meinteined by pieces of eppretus too cumbersome to use in the sverge institution. Some even have part of their eppretus leading down through the floor into the besernent: Some heve 2 suction apjertus so stremous thet it is responsible for much of a petient's pein. Denne'is trying to prove thet any empyeme. case will do at least as well with uis nethod as it will with Eny other. His method is this. Remove fifty to one hundred cubic centineters of pus, and replace thet volume with a like volume of eir, reperting this proceedure until all the pus has ben removed. The aspireting needle is put into the dependent pert of the cevity. The espiration his to be repected on an averege of three times, but is peinless if done properIy, end is much preferred by the petient who would rether undergoe lmost eny number of spiretions, if need be, than submit to a mejor surgicel proceedure. Allerth h mede e stetement, substantiating the principle of ir replacement. He seys thet, early in the course of the disease, it would seen advisebie to replace eech syringe of espircted fluid with a gringe of cir, thet intrepleurel pressure be kept stetionery. A sudden withdrawal of pressure fron ancctively hyperemic membrene must 
Treetment of finpyeme. Thorecis

result in en engorgment of this membrene with blood, and $c$ repid sucking up of toxic meteris 1 into the circulation. The lymph vesseds are wide open. Becterie end their toxic prom ducts sre limited to the endothelifi covering of the pleur by intrepleurel pressure, mecheniceliy closing these smell vessels. A sudden release of pressure, and the membrane becomes engorged with blood, with e resultant overdose of toxin and becterie liberated in the blood stretw. The sequelce of acute empyem can be enumereted is follows; first, death, due to pressure ceused by repid increase in size; second, chronic empyema; third, jerloretion of the empeme well, with formetion of secondery sinuses, ettended by destruction of lung tissue; fourth, bone infection with necrasis; fifth, empyeme necessitetis. Just $c$ word is necessary to cover empyeme necessitetis. It is one of the neturel terminetions of empyeme, but its mortelity is high. The most favorable is when the pus is evecueted spontaneousiy through a bronchus. It mey perforete the esophegus, the peritorieum, the pericardiurn, the stomach, or the chest wall. When it perforates the chest wall, it may be menifest as a pulseting tumor In the chest wall. Rarely, it mey pess down the spine end eIong the psoes into the iliec fosse, and simulete a psoes or 
Iumbar ebscess. Cases are on record in which an empyeme has pessed even further down, and pointed at the enkle. Briefly, the ceuse of chronic empyene is either inefficient dreingge, foreign body, failure of ckvity obliteretion, or tuberculous pleuritis. Chronic empyeme occurs either as deleyed healing, or es recurrence following dreinage. Emerson ${ }^{15}$ classifies chronic empyeme as follows: itirst, latent or undrained empyeme; second, delayed hecling, following early drainege; third, persistent, or recurrent enpyeme, following dreinge. Cerelessness in examinetion is responsible for the ceses in the first division of his clessification. Feilure to obtein pus on diegnostic espirotion is the man menifestation of this carelessness, and is due to failure of inserting the needle deeply enough. He stetes thet onehalf of chronic empyemas are due to the second division in his clessification, first because of partial healing of the drain hole; second, becuse of failure to secure deperident dreinage; third, because of inedequate drainege of secondary pockets; and, fourth, beceuse of incomplete irrigetion of secondery pockets. The third division of his classification is more often persistence then recurrence. The cavity mey enlerge after the sinus closes. In attempting to divine the 
cruses of this third division, he has listed certain factors in the rollowing order: first, reinfection (rore); second, early closure of the drainege sinus; third, associcted pethology, such ss multiple ebscesses and bronchiel fistulce. These fistule ore apt to become chronic, if the cavities are large, by preventing the infleting action of the increased intretracheal pressure during coughing, straining, etc., and siso by reinfecting the cevity. The chronicity may be augmented if the fistulee become lined by epithelium from the mouth of the bronchus. The fourth of the factors that Enerson has listed 5s ceusetive of persistent, or recurrent empyene is persistent infection in the pleura; fifth is tuberculous pleuritis (nine per cent of all); sixth is foreign bodies, as, for excmple, segments of rubber tubing, fregnents of necrosed rib, bismuth peste, eers of corn, sticks, teretomes, echinococcus cysts, bullets, etc.; seventh is ectinomycosis; eighth is massive compression of the lung; and ninth is fibrosis of the lung. Host concisely, the syntoms of chronic empyene ere chronic productive cough, with associeted menifestetions of sepsis such as aneenie, tecchycardia, multiple srthritis, clubbed fingers, and nephritis.

The cardinel principles in the surgical mangement 
of chronic empyema ere to avoid extrene surgieel risks; to preserve structure end function, es fer es possible; to select reconstructive, rather than mutileting operetions; and to use conservetive methods when in doubt. A number of different proceedures is avilable. They are discussed below in the order of their severity. The first, and least severe, is prelininary aspiration, with irrigetion by the closed metrod. Preliminary aspiretion should be done in every case. If tabercle bacilli are found, no open drainege should be done. (Sterile pus and many mononuclears are presumptive of a tuberculous lesion. In a case like this, repeated aspirations should be done when necessery to relieve the pressure, or espirations should be done with irrigetions, using some good antiseptic solution. Irrigetion should not be done, if the pleuritis is simple, that is, if it is not accompanied by thickening of the pleure.) The second proceedure is simple open drajnage. Simple open dreinage is indicated in cellulitis of the chest wall, in removing foreign bodies, in osteomyelitis of ribs, and in ceses in which there is a large bronchial fistula. Irrigation can be used safely, with on open operation, even in the presence of a lorge bronchiel fistule. After removing foreign bodies, the use of wolf's 
Treatment of Empyeme Thorecis

bottles to get expension and obliteration of the cevity is indicted. In regerd to intercostel open thorecotomy, Emerson says thatit's use may be justified as a temporery expedient to relieve pressure and circulatory emberrasment quickly in large, messive empyemas, with the condition of the patient very unfevorable. The third proceedure is open dreinage and exploration of the cevity for foreign bodies. The fourth is a decorticetion operction. This type of operation is indicated when the failure of obliterction of the cavity is due only to lung compression by a thick, fibrous cepsule. It is to be done, however, only when irrigation feils to promote recovery. Good results are not obtained if it is done in tuberculous pleuritis. Lilienthel's non-deforming operetion is less formidable, and less dengerous than the schede, the Fstlender, and the Dolorme-Fowler operctions. It is indiceted in those petients who, heving cevities and discherging sinuses, persisting for more than two months after drainage for empyeme, and unsterilizeble by the Cerrel-Dekin method, reverl, on exemination by the vertical fluoroscope, large rigid cavities and a profuse discherge. This operetion of Lilienthal mey be described or clessified as a mejor, non-collepsing thorecoplesty. The technicue is as follows: the approach is made through a 
Treatment of Fimpyeme Thorecis

long, seventh interspace incision, beginning behind the cost: 1 angle and extending to the cartilege. From one to four ribs are divided upwerd, and sometimes downward, et the posterior angle of the wound. A powerful automatic rib-retractor is necessery. The lung, bound down by cdhesions, is liberated by incision through the confining nembrene which mey be removed if there is an easily found line of clecvage. The lung is expanded by intre-pheryngeel insufflation, and should reach the chest well. Drainege is secured through the original sinus, enlarged for the purpose, the new surgical wound being closed by interrupted sutures of chromic cetgut through the muscles, but without the periosteal sutures. The efter treetment consists of strenuous blowing exercises. The fifth Eveilable proceedure is known as plastic operation, consisting of four types. There is the Estlender type, or simple ribresection; there is rib-resection ard excision of the parietal pleura; there is a plastic operation with muscle or skin trensplent; end there is extre-pleural thoracoplesty. Jones ${ }^{16 .}$ advises thoracoplesty for empyene with bronchiel fistule, end. in empyeme ofses, in which there is a non-collapsible cavity due to intra-pleursl adhesions within,which prevent lung expension, and a rigid roof, the chest weIl, without. His 
Treatment of Fimpyeme Thoricis

two mein consideretions in thoracoplesty ere adequate exposure and a good anesthetic, either nitrous oxide or parevertebral block. The plastic operetions for chronic pleuritis are indicated in ceses which fail to respond to a thorough course of irrigation menagement, those cases in which there are lerge sterile empyene cevities which fail to obliterate because of thickened pleurs, or in cases in which there is extensive cavitation in the lung, itself, with intrinsic fibrosis and contracted lung, or in cases of tuberculous pleuritis. The least formidable operation in this group is thet of Istlander. It consists of the removel of portions of one or several ribs, with a view to rendering the external wall of the suppurating dead spece elastic and to ellowing it to be depressed and brought in contact with the collepsed lung. Schedes operetion was to obliterate larger cavities, resulting from complete contraction of the lung. It affected a complete collapse of the chest wall. It is now obsolete, and is repleced by the paravertebrel extre-pleurel thorecoplastic operation of Seuerbruch.

A diagnosis of tuberculous empyeme cen be made reasonably safely if proven by biopsy or the dexonstration of tubercle bacilli, if there is a clinical picture of tuberculous 
Trestment of Empyeme. Thorecis

26.

empyem, if there is an empyeme in a petient with on ective

tuberculous focus, or if there is an idiopathic empyema or an empyeme in a petient heving a preceeding idiopathic pleurisy with effusion. In treating tuberculous ompyeme, the treatment is found to depend on the type of case; first, whether the cavity is open or closed; second, whether the exudate is serous, tuberculous, purulent (sterile), purulent from mixed infection, or hemorrhegic; third, whether the lung expends or remains collepsed upon withdrewel of the fluid; fourth, whether the fluid persistently reappears after each aspiration; and fifth, whether it is compliceted by bronchiel fistulae. The treatment of purulent or serous, tuberculous empyeme in the early stages is essentivily the seme, that is removal of enough fluid to relieve respiratory and circuletory embarrassment. Not enough should ever be removed to cause the tuberculized lung to expand. If there is denger of expension of a tuberculous lung, the fluid should be repleced by nitrogen gas. If there is little or no improvement, radical extre-pleural thoracoplasty mey be resorted to. Should this be found necessery, all the fluid should be aspirated from the cavity, the day before operation. If a petient with a sterile exudate is subjected to an open thoracotomy, a 
Treetment of Fimpyeme Thorecis

mixed infection will result, and this necessitates cn amount of radical surgery to which the patient should not be subjugeted. When there is found to be a tuberculous lesion near the pleural surface of the lung, twenty yer cent ergyrol solution should be substituted for Dakin's solution.

Glosed empyeme with mixed infection should be treated by the closed method if possible. If the closed method fails, the cevity can be sterilized and obliterated by the many-stage open method thet is used in cases of non-tuberculous chronic empyeme. Treetment of chronic tuberculous empyema, complicated by mixed infection, incident to en open thoracotomy, is practically the sane as thet used in the ordinary post-pneumonic and post-influenze type of chronic empyema, that is the many-stoge open operation with dakiniation of the cavity until sterile, and closure after seven consecutive, negative cultures heve been obteined. The tuberculous case differs in some respects, however. For example, in the chronic non-tuberculous open empyeme, the aim of the surgeon is to obliterate the cavity by methods thet will produce a minimum expansion with a minimus mutilation, and a consequent incresse in vital capacity, the amount of rib resection alweys depending on the power of the lune to expend. Ifore- 
Treatment of Empyem: Thoracis

over, in tuberculous empyeme, decorticetion is never done beceuse no expansion is desired. Then, too, tuberculous cases are kept open longer, for heliotherepy and the obliteration of cavities by thorecoplasty; also, muscle implents are used more freely. These cases are never good surgical risks, and they are more susceptible to surgical trcume. Although the mortality in shronic and supra-chronic non-tuberculous empyene has decreased with improved technique until it is now less then nine per cent, the nortelity in tuberculous empyeme has steedily incressed to eighteen and eight-tenths per cent for the reason that nore chences ere being taken than heretofore. Many are profoundly septic, mentelly depressed, and depressed physically; many heve cerdiac and renel conplications, snd heve alreedy had radicel operetions without relief.

Before considering plestic closure, the closure of bronchial fistulae deserves consideration, as no cavity with \& petent bronchiel fistula should be closed. Forty per cent of the bronchiel fistulee close sponteneously if the wound is laid open, and meny others will close after ceuterization, or after the applicetion of a three per cent alcoholic solution of gentien violet. Closure of larger fistulee is diffi- 
Treatrent of Fmpyema Thoracis

cult inasmuch es mobilization of a pert of a lobe or isolation of a bronchus, with a view to obliteration by suture, mey result in a lung or brain abscess, or in relighting a quiescent tuberculous process end unnecessery surgicel treimia. In the plestic closure, on implent with an atteched pedicle is used; the muscle is implented on surface thet hes been superficicliy decorticeted for its reception while the arm is held in the extreme verticel position. After several negative cultures, the skin and muscles are loosened and opproximeted, and held with sutures and adhesive tape. After three or four days, the sutures are removed because they ore not well tolerated by the frieble skin of tuberculous patients who have hed mixed infections of long duration. During the convelescence, the wound is held by adhesive as long as is necessery. Empyema thoracis is relatively comon in children. The etiological agentsin the case of empyeme in the child are the seme as those which obtein in the case of the cdult. Fmpyeme in children should never be trected by extensive open preumothorax becouse, inasmuch es a child's mediestinum is less rigid, the operation is usually fatal, especielly if performed early. Even with this edict, the high nortality in very young children stends unexpleined. It is rare to see acute 
empyeme followed by chronic empyeme in children. In treetwent, Douglas ${ }^{1 \%}$ recomends portial rib removel with secled siphon dreingge and no irrigation. The cevity will be oblitereted in children more repidly then in adults; so dreinege should be discontinued sooner. There is a tendency to thorecic deformity or posturel defects following empene in the growing child. On this sccount, therefore, it is wise to employ physiotherapy, to use greduated exercises, and to keep the child in touch with en orthopedics men. ,

The progress in undreined empyeme ceses will depend on the infecting egent and the generel resistance of the petient. Foster"believes it feir to assume thet deeth should never result from empyene thorecis per se; thet ohronic empyeme. should not occur in properly treated ceses of acute suppurating pleurisy; and that the besis of the determinetion of a cure should be the distppearance of all signs of sepsis, c complete obliteration of the empyeme cevity as arell as a healed superpicial wound, and a long-time follow-up. There is more to be seid in the future cbout the treatment of empyene. Such a varicnce of opinion, and such a diversificetion of results cre certein to encourage further investigation, presumebly of a beneficicl order. Then one 
realizes that one of the mejor strides hes been mede since the World War, one is forced to admit that further edvences are more than potentialities; and, furthermore, when one sess the tremendous amount of Inbor being expended on the problem at hend, one is likewise forced into believing thet the collocetion and subsequent correlation of these edvances is not far removed. As individuel physiciens, rather then rival specielists, we must all lend our concerted efforts towerd selving this problem, snd, further, to attrok it from a different angle, namely that of prophylexis. 


\section{Bibliogrephy}

1. Pilot, I. - Putrid Fnpyeme es e Post-operetive Complication, M. CIin. N. A., P. 1227, VoI. XIII, 1930.

2. Hudson, H. W. Ir. - Trestment of Acute Empyeme Thoracis;

A repert or tighty-six Cases, New Fing. H. J., P. 853, Vol. 202, 1930.

3. Lockwood, A. L. - Erapyeme, Acute and Chronic, Cened. M. A. J., F. 94I, VoI. XIV, 1924.

4. Suermondt, 耼. F. - Pleurel Mmpyeme, Deutsche Ztschr. f. Chir., F. 1, Vol. 186, 1924., ab. J. A, M. A. P. 394, VoI. 83,1924 .

5. Lilienthal, H. - Thorecic Surgery (Saunders), 1925. 6. Lennander, H.W., - Dtsch. Zeitschr. f. Chirurg., Vol. 81,

7. Roeder, C. A. - Gauze Fack in Empyenc of Pleural Gevity, An. J. Surg., P. 8, Vo1. 611, 1930.

8. Engstadt, J. Fi. - Simple Apperatus for Producing Negetive Pressure Following Thoracic Operetions, I1.- Lencet, F. 116, Vol. 50, 1930.

9. Panton, K. D. - Suction Drainege, Ganad. M. A. J., P. 368, Vol. 22, 1930.

10. Wensur, E. E. - Constent Vacuum Aspiretion Treatment; Simple Device in Creating Vacuum, Surg. Gynec. Obst., P. 1029, Vol. 50, 1930. 
Bibliography

11. Foster, L. C. - Treatment of Acute Empyeme Thoracis, with Report of one Hundred Fifty-Three Cases, Ann. Surg., F. 212, Vol. 92, 1930.

12. Singleton, A. 0. - Simplified Treetment of Thoracic Empyeme, Ann. Surg., F. 894, Vo1. 91, 1930.

13. Denne, J. A. - Treatment by Aspiretion and Air-Replacement

without Draingee, Inter. Nat.

ned. end Sure., P. 128, Vol. 43, 1930.

14. Allen, E. S. - Empyere And Influenze,

Kentucky M. J., P. 224, Vol. 28, 1930.

15. Fmerson, C. - Menegement; Intercostel open Thorecotomi,

Nebr. H. J., P. 76, Vol. 15, 1930.

16. Huerson, C. - Chronic Theyeme,

Nobr. I., P. 197, Vol. 15, 1930.

17. Fmerson, C. - Chronic Rmprene (Non-Tuberculous),

Nebr. M. J., P. 233, VoI. 15, 1930.

18. Jones, H. w. - Thorecoplesty for Empyeme with Bronchiel

Tistule,

Mil. Surg., P. 791. Vol. $66,1930$.

19. Douglas, P. - Pertiel Rib Removel with Closed Dreinege in

Acute Eripyeras,

Ann. Surg., P. 659, Vol. 91, 1930. 
Bibliogrephy

20. Cabrera, C. - Mpyeme Mecessitetis,

J. J. Phillipine Is., P. 413, Vol. 9, 1921 .

21. Horsley, J. S. - Treetment of ficute Tmpyeme of the Thorex, South, Hed. is Surg., P. 1, Vol. 92, 1930.

22. Proctor, 0. 5. - SurgiceI Treatment; Illustrated by Three CEses, North i. Ied., N.221, Vo1.29,1930.

23. KoIler, I. I. Treotment of Impyema Thorveis, onjo stete I. J., F. 21, VoI. 26, 1930. 


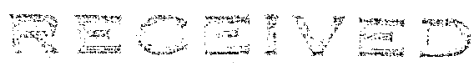

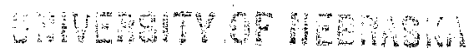

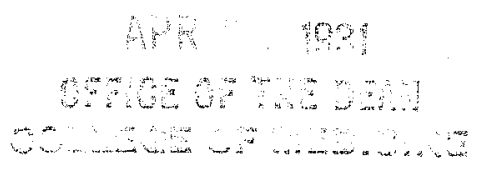

$-$ 